Sanja Stošić

Fakultet za diplomatiju i bezbednost Univerzitet Union Nikola Tesla
930.85(292.591)"15/18"

https://doi.org/10.18485/

filkult.2016.1.ch15

\title{
KULTURNA ISTORIJA FILIPINA - OD ŠPANSKE PROVINCIJE DO KOLONIJE
}

\section{Sažetak}

Da bi se na pravi način razumela kulturna istorija Filipina, neophodno je uzeti u obzir različite istorijske okolnosti pod čijim okriljem se odigralo ne samo osvajanje i duhovno pokoravanje već i društveno-politička hispanizacija ostrva. Osvajanje prekookeanske baze na Istoku imalo je za Španiju strateški značaj, te su neskrivene političke ambicije španske monarhije i rimokatoličkih misionara ka prozelitizmu direktno odredile osobenost kolonizatorskog diskursa i učinile da tokom XVI veka dođe do promene u društvenom uređenju Filipina. Postavljajući filipinske vođe na niže nivoe kolonijalne uprave, Španci su uspostavili tradicionalnu seosku organizaciju i obezbedili indirektan vid vladavine. Ovakav oblik vlasti potpomogao je da se u ruralnim krajevima Filipina formira nova viša klasa koja je, osim u političkoj moći, uživala u ekonomskim privilegijama i društvenom prestižu. Nekadašnje trvenje među urođeničkim zajednicama između kojih nije bilo krvnih saveza utihnulo je sa pojavom superiornih političkih figura. Nakon što su postigli da nativno stanovništvo Manile i susednih provincija (Ilokosa, Lagune i Pangasinana) prizna španski suverenitet, tokom XVII i XVIII veka španski kraljevi nosili su titule „prirodnih“ vladara Indija, a Filipinci su u načelu dobili ravnopravan status kao građani Španije.

Ipak, politički događaji XVIII i XIX veka uzdrmali su status Filipina kao redovne španske provincije, ogolivši političku volju Španije usmerenu ka potčinjavanju filipinske kolonije. U tom smislu, u periodu od XVI do XIX veka filipinsko društvo doživelo je suštinski transformativan proces $u$ kome kolonijalni sistem nije mogao da funkcioniše kao tačno utvrđeni model u različitim kontekstima, već je pre delovao kao jedna vrsta rušilačke sile koja je neminovno vodila u pravcu konstituisanja kulturnog identiteta.

Ključne reči: Španija, kolonizacija, Filipini, hispanizacija, kulturni identitet 


\section{Umesto uvoda}

Osnovni izvori za istraživanje Filipina španskog kolonijalnog perioda uglavnom su hronike koje su pisali španski misionari (avgustinci, rekoleti, franjevci, dominikanci) od sredine XVI veka. Kao dela nastala od strane kolonizatora, ova dela ukalupljena su u kulturno-civilizacijski okvir hrišćanske katoličke misli, zbog čega ih, prema mišljenju pojedinih autora, odlikuje izrazito odsustvo kritičke perspektive te se zapravo ne bave istorijom Filipina, već istorijom Španije na Filipinima (Sánchez Gómez 1995, 2).

Sa druge strane, većinu autora XIX veka karakteriše zatvorenost prema kulturološkim različitostima, pa se u njihovim delima filipinsko autohtono stanovništvo opisuje kao "ograničeno“ (Monteverde y Sedano 1989), zbog čega su stanovnici planinskih predela severnog Luzona za engleske autore pagans, non-Christians, headhunters ${ }^{1}$ ili, u još gorem slučaju, savage, primitive, barbaric, uncivilized ${ }^{2} i$ sl. Nasuprot tome, za većinu španskih autora ovi narodi su infieles, ${ }^{3}$ odnosno oni koji se ne uklapaju u podelu stanovništva na moros, negritos i indios, ${ }^{4}$ jer nisu tako lako mogli da budu hispanizovani. Ipak, neosporno je i da su neki španski autori iz druge polovine XIX veka negirali postojanje bilo kakvog oblika filipinske civilizacije pre dolaska Španca, kao i da je u mnogim dnevnicima, pismima i memoarima osvajača, kulturološki profil Filipina obojen zapadnjačkim kulturološkim šovinizmom, pa su kasnije mnoge od ovih pojednostavljenih tumačenja bojni istoriografi XX veka prihvatili kao istorijske činjenice.

$\mathrm{U}$ tom smislu, adekvatna analiza filipinske kulturne matrice neminovno obuhvata podrobno proučavanje i filipinskih i malajskih tekstova, kao i ranih kineskih istorija i carskih trgovinskih izveštaja i putopisa svedo-

1 „Pagani, nehrišćani, lovci na glave“ (Prev. aut.).

2 „Divlji, primitivni, varvarski, necivilizovani“ itd. (Prev. aut.).

3 "Nevernici“(Prev. aut.). Španci su autohtono stanovništvo određivali ne prema etničkoj pripadnosti, već prema religiji, razlikujući tako pripadnike islamske vere (moros) od onih koji to nisu bili (gentiles). Kasnije, oslanjajući se i na geografski kriterijum, Španci su napravili razliku između onih koji su živeli u planinskim predelima u unutrašnjosti arhipelaga (negritos) i stanovnika koji su živeli u priobalnim područjima (indios). Muslimane, Crnčiće i Indijce. (Prev. aut.). Zapravo, rani španski hroničari su greškom nazvali Filipine Indijama, odnosno Indias ili Indies i samim tim su i Filipince pogrešno klasifikovali kao Indijce (indios). Tek nakon što je arhipelag u čast španskog kralja Filipa II nazvan Filipinas, narodi ovih ostrva mogli su da se nazovu Filipincima. 
ka koji su dolazili iz Kine i dobro poznavali kulturne prakse svojstvene celoj Jugoistočnoj, ${ }^{5}$ a možda i Istočnoj Aziji (Junker 1998, 296-297). ${ }^{6}$ Istovremeno, novija arheološka istraživanja i savremeni pristup etno-istorijskim izvorima, omogućavaju sagledavanje raznih skrivenih aspekata vezanih za prirodu filipinskih poglavištava (barangays) ${ }^{7}$ i dinamiku njihovog prerastanja u gradove-državice. ${ }^{8}$ Naime, organizacija filipinskih naseobina u prehisanskom periodu, uređenost domaćinstava, zatim specifičnost pogrebnih običaja, načina života i ishrane, kao i drugi arheološki pokazatelji razvijene sociopolitičke strukture, ukazuju na postojanje plemenskih društvenih zajednica različite razvijenosti koje su činile sastavni deo filipinskog kulturološkog mozaika barem još od prvog milenijuma nove ere, a verovatno i ranije (Junker 2000,5$).{ }^{9}$ Zapravo, još u ovom periodu na Filipinima postojala je specijalizacija zanata i prozivodnje, ${ }^{10}$ što je bio preduslov za razvoj premodernog društvenog uređenja u kome su se različite lokalne glavešine nadmetale za prevlast nad proizvodnjom i distribucijom prestižnih dobara i usluga kao osnove za uvećanje svoje ekonomske, političke i ritualne moći.

Ovakav društveni i ekonomski ambijent bio je pogodan za konstituisanje većih naseobina ili gradova, odnosno slika i prilika ranog filipinskog državnog uređenja. Konačno, iako je generalno ekonomija prehispanskih filipina bila na nivou održivog razvoja, tj. usmerena ka zadovoljenju

5 Organizovanje ritualnih gozbi, otimanje robova, primogenitura u nasleđivanju, poligamija, izrazito ceremonijalni karakter suđenja kao moćna forma političke integracije, pokroviteljski odnos elite prema slugama i štićenicima itd.

$6 \quad$ Kros-kulturalno proučavanje istorijske baze vezane za prehispanski i hispanski period i različita arheološka istraživanja ukazala su na neosnovanost određivanja filipinskih društava kao zajednica formiranih isključivo pod stranim kulturološkim uticajima.

7 Sam termin poglavištva koristi se da bi se opisala struktura filipinskog socio-političkog sistema u prehispanskom periodu. (Earle 1987) definiše poglavištva kao: „Regionalno organizovane političke entitete sa centralizovanim upravljačkim i hijerarhijski koordinisanim aktivnostima između nekoliko seoskih zajednica“ (288).

8 Filipinski gradovi-državice razvili su se u geografski sličnom okruženju kao i antički, tj. bili su podjednako rascepkani i funkcionisali su kao nezavisna jezgra političkog i društvenog života, te je sasvim prikladno upotrebiti i pojam filipinski polisi. (prim. aut.)

9 Sudeći po ostacima čamaca iz 320. god. naše ere pronađenim na severoistočnom delu ostrva Mindanao, stanovnici Filipina bavili su se pomorskom trgovinom barem još od IV veka (Patanñe 1996).

10 Prema arheološkim istraživanjima, u periodu 500-1600 god. pre Hrista, u oblasti visajskih Tandžaja (Negros Oriental) uporedo sa proizvodnjom i razmenom keramičkih predmeta na lokalnom nivou, negovalo se i umeće grnčarije i izrada keramike isključivo za vladajuću elitu i inostranu trgovinu (Niziolek 2013, 36). 
osnovnih životnih potreba, a ne akumulaciji bogatstva, ${ }^{11}$ preživljavanje određenih društvenih zajednica bilo je usko vezano za trgovinske aktivnosti, a između lovačko-sakupljačkih zajednica Negritosa (Crnčića) naseljenih duboko u šumama u unutrašnjosti arhileplaga i manjih, plemenski organizovanih, društava koja su naseljavala priobalne ili planinske predele i bavila se zemljoradnjom i uzgajanjem pirinča postojala je jaka međuzavisnost. ${ }^{12} \mathrm{U}$ tom smislu, da bi se stvorila šira slika o evoluciji filipinskog društvenog poretka neophodno je uzeti u obzir ne samo istorijska dokumenta koja jasno ističu etničke, ekološke i evolucione razlike među pojedinim regijama arhipelaga nego i kulturno-istorijski kontekst u kome su dati istorijski izvori nastali.

U periodu od XVI do XIX veka Španija i Meksiko izvršili su jak kulturološki uticaj na Filipine. Legaspi je 1571. godine osvojio ostrvo Luzon i zvanično osnovao Manilu kao glavni grad Filipina, a ubrzo se konsolidovala i pomorska ruta Galeona iz Manile (Galeón de Manila) na osnovu koje je Španija preko Sevilje i meksičke luke Akapulko ostvarila viševekovnu kontrolu nad zonom transpacifičke trgovine, dok je Manila, zahvaljujući razvijenim komercijalnim i ekonomskim aktivnostima sa Kinom, Japanom i Jugoistočnom Azijom, postala središte prve globalne trgovinske mreže i bastion španske kolonizacije Mikronezije i širenja katoličanstva na području Orijenta. Udaljenost Filipinskog arhipelaga od prestonice, kao i geografska razuđenost i etnička raznolikost ostrva, doprineli su mirnodopskom osvajanju i sinkretičkom razvoju filipinske tradicionalne kulture i hispanskih kulturnih elemenata. ${ }^{13}$ Istovremeno, azijski uticaj uticao je na specifičan ekonomski razvoj ostrva, stvorivši podlogu za „kulturnu hibridnost“ filipinske zajednice (Gonda and Zvelebil 1975). To-

11 Primer koji to ilustruje jesu zajednice Pampanga i Pangasinana koje su naseljavale planinske predele i imale pristup nalazištima ćilibara i zlata ili životinjskim smolastim materijalima poput cimeta i mošusa i eksploatisale su ove resurse isključivo radi zadovoljenja svojih osnovnih životnih potreba.

12 Etnoistorijski izvori navode da je stanovništvo iz unutrašnjosti arhipelaga izvozilo lako kvarljivu robu poput šumskih plodova, životinjske kože, pčelinjeg voska, smole, lekovitog bilja ili drveta. Nasuprot tome, trgovci iz ravničarskih predela nudili su robu poput keramičkih proizvoda lokalnog porekla, ali i prestižnih dobara kao što je metalno oružje, ukrasna grnčarija i uvezeni kineski porcelan (Junker 1996, 398).

13 Primer koji to najbolje ilustruje svakako je prisustvo velikog broja crkvenih lica koja su u kontinuitetu naseljavala ostrva, vršila mirnu jevanđelizaciju nad urođenicima i kontrolisala proces kolonizacije, pretvarajući Filipine u „zemlju misionara i katoličanstva“" (Phelan 2011). 
kom XVI veka islamski uticaj koji je već bio osetan na jugu Filipina postepeno se širio ka severu, dopirući čak do Cebua i Manile (Phelan 2011). lako je neposredno pred dolazak Španaca islam prodro na Visajska ostrva i Luzon, hispanizacija je zaustavila njegovo širenje, posebno u predelu plodnih rečnih dolina (Scott 1984).

Fokus ovog ovog rada prvenstveno je usmeren ka izučavanju dominantnih društveno-političkih i kulturnih modela nastalih u periodu od XVI do XIX veka, kada je filipinsko društvo kroz različite etape doživelo suštinski transformativan proces sučeljavanja evropskog i azijskog principa i istovremenog prožimanja lokalnih i kolonizatorskih kulturnih praksi. Kako je španski uticaj bio najjači u oblasti Luzona i Visaja, ove oblasti i narodi koji su ih naseljavali izdvojeni su kao presudni za evolucioni proces celokune filipinske zajednice.

\subsection{Prehispanski Filipini i značaj hispanizacije}

U prehispanskim Filipinima postojala je izrazita društvena stratifikacija, ali je sa hispanizacijom došlo do procvata političke ekonomije i jačanja vladajuće klase koncentrisane u Manili. Zapravo, Filipini su postali deo španskog kraljevstva sa dolaskom Legaspijeve ekspedicije, a sam period 1565-1585 godine bio je odlučujući za uspostavljanje kolonije i miroljubivo osvajanje i preobraćanje autohtonog stanovništva. Tokom ranog $\mathrm{XVI}$ veka u priobalnim predelima i rečnim dolinama većine istaknutih filipinskih ostrva postojale su razvijene društvene zajednice veoma raslojene i složene u društveno-političkom smislu. Sa kulturološkog aspekta, ove zajednice mogu da se definišu kao poglavištva (chiefdoms), tj. društva koncentrisana oko nasledne elite ili razvijene društvene zajednice u kojoj je glavešina arbitar grupe i stručni savetnik. Sa sociološkog aspekta, veliki broj barangaja borio se za ekonomsku i političku prevlast putem kontrole trgovine ne samo na regionalnom već i na inostranom nivou, a karaktersala ih je društvena struktura izdrađena na privremenim savezničkim koalicijama. ${ }^{14}$ Osim toga, na razvoj i društveno uređenje barangaja uticalo je i

$14 U$ većini zajednica postojala je prepoznatljiva aristokratska (datu) loza čiji su pripadnici rođenjem sticali sledbenike, što je dovelo do stvaranja lokalnih gospodara sa individulanim političkim pozicijama koji su, zauzvrat, jednom od njih kao vodećoj ličnosti priznavali nasledno pravo na odanost i vernost svih ostalih. Na taj način nastala je klasa vlastodavaca (principalía) sa manje ili više centralizovanim političkim uređenjem. 
specifično ekološko i geografsko okruženje Jugoistočne Azije, kao i različiti obrazci u porastu broja stanovnika u zavisnosti od resursa. Generalno, tokom $X$ i XI veka kada su Kinezi primarno trgovali preko Južnog kineskog mora, razvili su se gradovi na severozapadnim obalama Luzona i Mindora, a tokom XV i XVI veka kada se trgovina odvijala preko Javanskog mora kao moćni ekonomski i politički centri izdvojili su Suluu i Mindanao. U tom smislu, priroda i razvoj filipinskih poglavištava zavisili su pre od dinamičke interakcije između ulaganja u trgovinu luksuznim dobrima i drugih oblika lokalnih političkih ekonomija koje su bile u povoju, nego od samih inostranih uticaja.

Po dolasku na Filipine Španci su zatekli mnoštvo različitih etničkih grupa koje su karakterisali donekle slični običaji, ali i kulturološke specifičnosti. Tokom prve polovine XV veka političko uređenje svih krajeva filipinskog arhipelaga nije prevazilazilo okvire plemenskih saveza i prava feudalne vladajuće klase ${ }^{15}$ već je isključivo počivalo na priobalnim zajednicama ili barangajima između kojih su često izbijali sukobi. “(...) These conflicts were understandable because each barangay was, as indicated, an independent, political, social, and economic unit. Each one therefore sought to safeguard the interests of its members" (Jocano 1975, 173). ${ }^{16} \mathrm{U}$ vreme španske kolonizacije prehispanski barangaji bili su u procesu tranzicije i obuhvatali su zajednice različitog nivoa razvijenosti, od primitvnih, manjih i izolovanih, pa sve do onih uređenih po principu „azijskog feudalizma" razvijenog na jugu Filipina. ${ }^{17}$ Kako su i manje razvijeniji barangaji bili su socijalno raslojene i samoodržive zajednice čiji su stanovnici mahom bili poljoprivrednici ili zanatlije, oni su sami proizvodili sve što im bilo potrebno, što je otežavalo razvoj eksploatatorske klase.

Kada je reč o izboru vođe, glavešina barangaja morao je da bude harizmatičan i hrabar, a njegova moć direktno je zavisili od njegove mogućnosti da se stalno ističe u ratnim podvizima i drugim aktivnostima

15 Izuzetak su bile oblasti na jugu Filipina koje su se nalazile pod muslimanskom vlašću.

16 ")(...) Ovi sukobi su bili razumljivi jer je svaki barangaj bio nezavisna politička, društvena i ekonomska jedinica. Stoga, svaki barangaj je nastojao da zaštiti interese svojih članova." (Prev. aut.).

17 Na ostrvu Sulu i Magindanao društvene zajednice su bile pod centralnom vlašću sultana, a zemlja koja je bila u vlasništvu zajednice, obrađivala se kao privatan posed. Vođe su imale funkciju upravnika imanja, ali i političkih funkcionera na čelu zajednice i istovremeno su bili uživaoci viška vrednosti koji je nastajao radom ostalih članova zajednice. Na taj način, za muslimanske barangaje je bila tipična dezintegracija komunalne i egalitarne organizacione kuture (Constantino 1975, 37). 
presudnim za opstanak i blagostanje barangaja. Kako su Španci prve naseobine podigli u centralnim delovima Manile i Sebua, prve hronike nude opširne opise društvenog uređenja Tagaloga ${ }^{18} \mathrm{i}$ Visaja ${ }^{19}$ iz kojih se vidi da su u odnosu na ostale etničke grupe ovih prostora, Tagali i Pampange dostigli najviši stepen razvoja, zbog čega su i za formiranje nacionalnog identiteta Filipina ove oblasti bile od ključne važnosti. ${ }^{20}$ Prema opisima Antonija de Morge (Antonio de Morga) i Huana de Plasensije, za razliku od Visaja, na Luzonu je bila razvijenija trgovina i ekonomske aktivnosti, bio je osetniji politički uticaj Bornea, a osnovna poljoprivredna delatnost bila je uzgajanje pirinča. ${ }^{21}$ Legaspi je u svojim spisima istakao monopolističku ulogu luzonskih i borneanskih brodova u filipinskoj trgovini, dok su visajske naseobine duž obala Panaja, Negrosa, Sebua, Bohola, zatim na ostrvu Lejte, Samar i severoistoku ostrva Mindanao, obuhvatale manje društvene zajednice i ekonomiju zasnovanu na eksploataciji tla metodom seci, spali i posadi, ubiranju plodova iz šuma i mora i piratske aktivnosti. Zbog takvog načina života Visajci su usavršili tehniku izrade brzih ratnih brodova koji su mogli da plove i u oblasti plitkih voda, a samo društveno uređenje počivalo je na modelu „gospodara i klijenta“ (Scott 1992, 86-92).

Naseobina sačinjena od jednog barangaja zvala se pook, dok su se naseobine sa više barangaja zvale bayan (Mateo 2001, 29). Određene za-

18 Najznačajniji izvor informacija o društvu Tagaloga predstavlja delo franjevca Huana de la Plasensije (Juan de la Plasencia) koji je verovatno bio autor prve štampane tagalog-španske kateheze o katoličkoji veri 1892. god. Pre toga, u opticaju su bile različite verzije rukopisa, a samo delo je špansko sudstvo prihvatilo kao zbornik običajnog prava Tagaloga. Inače, Plasensija je imao odlučujuću ulogu u naseljavanju filipinskog stanovništva u kompaktnije seoske zajednice i promociji obrazovanja.

19 Jedno od kapitalnih dela za razumevanje društva Visajaca jeste rukopis Fransiska Ignasia Alsine (Francisco Ignacio Alcina) Historia de las islas e Indios de Bisayas. Osim toga, kao značajne izvore takođe bi trebalo pomenuti i hroniku Migela de Loarke (Miguel de Loarka) iz 1592. god. i delo Antiguas leyendas (1578) Dijega Lopesa de Povedana (Diego López Povedano).

20 I kod Tagaloga i kod Visajaca određeni duštveni status sticao se rođenjem, a, u načelu, u okviru društvenog poretka izdvajale su se tri klase: datu, timawa i oripun. Zapravo, većina stanovništva društvenih zajednica Tagala i Visajaca pripadala je upravo klasi potčinjenih ili običnih ljudi jer su se skoro sve sudske presude sprovodile plaćanjem kazni, a oni koji nisu bili u stanju da isplate novčane kazne ili osiguraju zajam isplativ krajem žetelačke sezone uz kamatnu stopu od $100 \%$ zapadali su u dužničko ropstvo. Osim toga, brojnost pripadnika klase potčinjenih održavala se ne samo zahvaljujući praksi kažnjavanja već i čestim pohodima na susedne barangaje iz kojih su dovođeni zarobljenici (Phelan 2011, 20). Pirinač se gajio u oblasti Pampange, a duž obala Lagune de Baja rastao je u toliko dubokoj vodi da se žetva vršila iz čamaca. 
jednice bile su specijalizovane za izradu grnčarije, alata, metalnih ukrasa, drvenih korpi, šešira i morskih proizvoda poput soli i sušene ribe, a njihovi članovi koji su trgovali u udaljenim zajednicama bili su zaštićeni krvnim savezima koji su omogućavali porodična, ali i trgovinska udruživanja (National Exhibition of Filipino Pre-history and Culture 1959). lako je na osnovu španskih izvora donekle moguće utvrditi prirodu uzajamnih obaveza među srodnicima, teško je steći dublji uvid o njihovoj važnosti u okviru barangaja kao jedine stalne političke jedinice. Kako Felan (Phelan 2011) primećuje, primarni elementi društvene strukture barangaja počivali su upravo na sistemu srodničkih veza i odnosa i dok je na Luzonu npr. preovladavao patrilokalni tip nastanjivanja i nasleđivanja imovine, na Visajima je postojala jaka tendencija ka matrilokalnom obrazacu (20).

Uprkos tome što su Španci doživljavali Filipine kao daleko i egzotično mesto, ne baš prijatno i prijemčivo za život, Manila je delovala primamljivo i intrigantno jer je zbog dobro razvijene trgovine između Španaca, Meksikanaca i Kineza nudila priliku da se zgrne bogatstvo. Upravo stoga, za Špance Filipini su predstavljali paradoks i istovremeno su doživljavani i kao granica španskog kraljevstva, ali i kao put ka Istoku. ${ }^{22}$ Sam stepen hispanizacije bio je najviši upravo u Manili i njenoj okolini, ali je u ostalim predelima Filipina bio na minimalnom nivou. lako je španska zajednica bila mala, u odnosu na kolonijalnu upravu bila je moćna. Na izvestan način, kolonijalni ambijent Filipina temeljio se na principu ucene, budući da su svešenici, u sukobu sa biskupima i velikodostojnicima, pretili odricanjem od hrišćanske doktrine, a susedi Manile, iziritirani uvoznim nametima i porezima na trgovinu koja se odvijala rutom galeona iz Manile, odlaskom u Novu Španiju (Meksiko). Istovremeno, sama činjenica da je Manila bila izgrađena kao utvrđenje opasano bedemima doprinosila je specifičnom ambijentu unutar grada u kome je postojala stalna bojazan od nereda i napada kako spolja (od Holanđana i Engleza) tako i iznutra (od strane Kineza i Filipinaca). Budući da Španci nisu imali potpunu kontrolu nad kolonizovanim sugrađanima, trgovinskim tokovima i spoljnim pretnjama, Manila je bila jedan zaseban svet u kome se razvio specifičan

22 Filipini su bili teritorija koja je istražena i kolonizovana od strane sveštenika. lako je bilo slučajeva hispansko-filipinskih mestika, njihov broj je zanemarljiv jer je španska populacija bila mala. Uprkos tome, Manila je oduvek privlačila kinesko stanovništvo koje se progresivno naseljavalo na ostrvima, naročito u Manili i okolini. Sredinom XVIII veka, mestici iz Šangaja su u Manili i okolini činili četvrtinu oporezivanog stanovništva. 
način života koji je za većinu žitelja bio vezan za egzotičnu, ali i rutinsku i monotonu svakidašnjicu zajednice u kojoj je dominiralo iščekivanje kineskih brodova i galeona iz Akapulka, kao i opšta neizainteresovanost za zemljoposedništvo, dok je za sveštena lica ovaj život prvenstveno bio usmeren ka uspostavljanju misionarske države.

Od osnivanja Manile kao prestonice, grad je zadobio status gradske skupštine (cabildo secular ili ayuntamiento). ${ }^{23}$ Prema španskom zakonodavstvu, autohtono stanovništvo Filipina imalo je status nacionalne manjine i uživalo je zaštitu španskog kraljevstva i podanika Krune. Sa administrativnog aspekta, urođenici su tretirani kao politička zajednica naroda (la república de los Indios) sa sopstvenim zakonodavstvom i sudijama, a u odnosu na prehispanski period, postkolonijalni barangaj karakterisala je stabilnost i horizontalna mobilnost. Gradska uprava Manile bila je odgovorna za snabdevanje grada, utvrđivanje cena i količine osnovnih životnih namirnica i proizvoda. Međutim, za vreme vladavine Karlosa III (17591788) i uticaja prosvećenog apsolutizma težilo se stvaranju racionalnijeg sistema kraljevske administracije. Kako su troškovi odbrane kraljevstva konstantno rasli, jedan od osnovnih političkih ciljeva kraljevskih činovnika bilo je pronalaženje načina da se uveća kraljevski prihod, zbog čega je 1786. god. forma klasičnog barangaja modifikovana, a uprkos tome što je Kraljevski vrhovni savet Indija imao funkciju najvišeg Žalbenog suda za španske kolonije, parnice Filipinaca retko su bile predmet zasedanja Žalbenog veća jer je španska uprava nastojala da obeshrabri Filipince da se upuštaju u dugotrajne sudske procese (Cunningham 1979, 99-104). ${ }^{24}$

Tokom XVI i XVII veka, učestali napadi Holanđana i Engleza zainteresovanih za Indiju i Jugoistočnu Aziju, odredili su Filipine, a naročito Manilu, kao trgovačku enklavu na granici španskog kraljevstva. Strah od napada holandske armade i engleske ratne flote suštinski je promenio društveni život u Manili, zaustavljajući trgovinu galeona iz Akapulka i plasman srebra u Evropu i Aziju. Budući da je svetska ekonomska politika od

23 U skladu sa uredbama vicekraljevstva Meksika, pod čijom upravom su se nalazili Filipini, 19. novembra 1595. godine Filip II proglasio je Manilu prestonicom Filipinskih ostrva. Na taj način Manila je zvanično dobila odobrenja i privilegije koje su imali i ostali gradovi kraljevstva.

24 lako su Španci omogućili Filipincima da traže svoja prava pred Vrhovnim sudom, pripadnici klera dovodili su u pitanje primenu španskih sudskih procedura u lokalnim sprovima, smatrajući urođenike moralno nestabilnim i sklonim laganju. 
XVI do XVIII veka počivala na ideji o merkantilističkom društvu u kome je vladala groznica za plemenitim metalima i akulmulacija bogatstva putem protekcionizma, ${ }^{25}$ početak trgovine galeonima bio je usko povezan sa razvojem merkantilizma, ali je razvoj međunarodne trgovine istovremeno bio ograničen suprotstavljenim interesima drugih velikih svetskih sila.

Da li je dolazak Španaca unapredio ili usporio prirodni tok razvoja autohtonih društava otvoreno je pitanje, ali je nepobitna činjenica da je proces hispanizacije ${ }^{26}$ suštinski preoblikovao postojeće društvene sisteme i tok filipinske kulturne matrice. Španci su posvetili dosta pažnje jezicima i verovanjima svih etničkih grupa koje su bile pod njihovom kontrolom i u cilju što efiksanijeg pokatoličavanjana učili su tagalog jezik i štampali su knjige koristeći baybayin, tj. znakove starog tagalog pisma. U proučavanju istorijskih izvora, istorijsko-pregledni metod omogućio nam je da izvršimo istoriografsku analizu i sintezu podataka dobijenih iz različitih primarnih i sekundarnih istorijskih izvora i obuhvatimo kako istorijske okvire i tumačenja istoričara iz daleke prošlosti tako i interpretacije različitih istorijskih, etnoloških, antropoloških i filoloških studija koje pripadaju savremenom dobu. Na taj način, od opšte prihvaćenih stavova prisutnih u različitim okvirima i kriterijumima relevantnim za razumevanje datog perioda, deduktivnim metodom izdvojili smo pojedine društveno-političke aspekte važne za kulturnu istoriju Filipina i formiranje filipinskog nacionalnog identiteta.

\section{Filipinci, građani Španije?}

Imperijalistička ideologija kraljevstva duboko je bila prožeta idejama Fransiska de Vitoria (Francisco de Vitoria) ${ }^{27}$ koji urođenike nikako nije video u svetlu civilizovanih naroda. Naime, 1570. god. avgustinci nisu uopšte

dovodili u pitanje pravo Španaca da kolonizuju arhipelag, ali su se u skla-

25 Odnosno ohrabrivanja izvoza i obeshrabrivanja uvoza, posebno uz pomoć carinskih dažbina i poreza.

26 Pojam hispanizacije upotrebio je Felan (Phelan 2011) da bi označio proces koji je prouzrokovao duboke društveno-ekonomske promene koje su obeležile način života na Filipinima u vreme španske okupacije. lako neki autori osporavaju upotrebu ovog termina pošto krajnji produkt španske kolonizacije nije deo španske koliko filipiniske kulture, u sociološkom smislu njegova upotreba je opravdana jer ukazuje na stanje koje na Filipinima pre dolaska Španaca nije postojalo. Fransisko de Vitoria bio je istaknuti dominikanac i profesor teologije u Salamanki. V. detaljnije (Scott 1934). 
du sa instrukcijama Filipa II prilikom osvajanja izrazito protivili upotrebi sile i tiraniji. Budući da u centralnom i severnom delu arhipelaga nije bilo nikakvog oblika državno-političke organizacije, već samo primitivnog sistema prinudne naplate i zakona jačeg, Španci su se rukovodili stavom da zapravo imaju moralnu obavezu da obrazuju i prosvetle „kulturno inferiorne“ domoroce. U tom smislu, crkveni sabor održan 1582. godine produbio je ideju o legitimnosti kastiljanskog suvereniteta nad Filipinima, tumačivši ga kao obavezu propovedanja jevanđelja i pružanja zaštite preobaćenicima od njihovih paganskih suseda. ${ }^{28}$ Međutim, tvrdnja o "univerzalnoj vladavini“ Kastilje nad Indijama postala je oko 1590. god. predmet rasprave između dominikanskog biskupa Dominga de Salasara (Domingo de Salazar) ${ }^{29}$ i Migela de Benavidesa (Miguel de Benavides). Usvajanje ovakvog stava na pomenutom saboru bilo je zapravo odraz prezira kako kolonizatora tako i misonara prema potčinjenim, „divljim i nerazvijenim“ Filipincima, odnosno čisto pitanje sekularne ili klerikalne prevlasti nad osvojenim teritorijama i naplate danka. ${ }^{30} \mathrm{U}$ periodu $1581-1586$ održana su ukupno četiri crkvena sabora, a Alonso Sanćes (Alonso Sánchez) se trudio da uspostavi skladne odnose između svetovne i crkvene vlasti u okviru koje je postojao unutrašnji raskol oličen u suprotstavljenim interesima dominikanaca i jezuita. ${ }^{31}$.

$28 \quad$ Na saboru je potvrđeno pravo pape da smeni lokalne vladare koji ometaju aktivnosti misionara, kao i poštovanje individualnih, političkih i svojinskih prava urođenika koja nisu bila u koliziji sa širenjem jevanđelja.

29 Salasar je bio protivnik nemilosrdne eksploatacije urođeničkog stanovništva. Poput Salasara, i drugi filipinski biskup, Benavides, osuđivao je predlog Hosea de Akoste (José de Acosta) da se nepokrštenim stanovnicima nametne plaćanje danka, dok je Akosta smatrao da je besmisleno oporezivati pokršteno stanovništvo jer bi versko podučavanje trebalo da bude besplatno. Nasuprot tome, jezuiti su odbacivali Akostinu doktrinu, smatrajući da bi se Filipinci više opirali preobraćanju ukoliko bi shvatili da su nepokršteni stanovnici u povoIjnijem položaju od pokrštenih.

30 Odredbe Aleksandrijskih bula koje su kastiljanskim kraljevima pripisale pravo na Novi svet, nominalno su opravdavale božansku vladavinu i zaštitu urođeničkih prava, jer su kraljevi, kao „univerzalni gospodari Indija“, imali svetu obavezu da „bezbožne“ narode upoznaju sa blagodetima katoličke vere, što je otklonilo i kontroverzu opravdanosti osvajanja Filipina. Sanćes je podržao odluke sabora prema kojima zlodela počinjena od strane kraljevih podanika nisu mogla da naruše pravo pape i monarha da šalju crkvena lica da propovedaju jevanđelje i vojnike koji su štitili njihovu misiju. Ipak, ukoliko kralj ne bi sankcionisao nasilničko ponašanje svojih podanika, Sanćes je smatrao mogućom pobunu protiv opresivnog kastiljanskog režima, čime je predvideo zbacivanje španske političke vlasti od strane urođenika, uz opstanak klera pod svetovnom vlašću novog režima. Njegove pretpostavke potvrdile su se tokom XVII veka kada je došlo do lokalnih pobuna koje su počele kao protesti protiv teških nameta i drugih zloupotreba od strane kolonizatora. 
Prema Salasaru, postojale su samo dve vrste suvereniteta nad čovekom: prirodna ili potpuna vlast vladara nad određenom teritorijom koja se ogleda u njegovoj obavezi da sprovodi pravdu i štiti svoje podanike, i božanska, apsolutna ili natprirodna vlast oličena u liku klera čija je misija da vodi ljude ka putu večnog spasenja. lako je u Španiji Filip II bio „prirodni vladar", na Filipinima je jedino mogao da ima funkciju „natprirodnog vladara“, a „prirodni suverenitet“ nad ovim prostorima Filip II je mogao da stekne samo izborom i slobodnom voljom urođenika ili „opravdanim ratom“. Međutim, budući da na Filipinima ništa od prethodno navedenog nije bio slučaj, Salasar je izjednačio božansku vlast crkve sa vlašću koju je Hrist imao nad svojim sledbenicima. ${ }^{32} \mathrm{Na}$ taj način, iako Sveta stolica nije imala direktnu vlast nad autohtonim stanovništvom, sveštenstvo je zapravo imalo obavezu da nametne svoju vlast „bezbožnicima“ radi ostvarenja Božje vladavine (Phelan 1957, 221-226).

Kako na Filipinima nije postojao nikakav oblik crkvene organizacije koja bi se borila za svoja prava, religijska ubeđenja Tagala i Visajaca nisu predstavljala preveliku prepreku širenju hrišćanstva. Ipak, krajem XVI veka savetnici kralja i teolozi uvideli su da je zasnivanje kastiljanskog suvereniteta na Filipinima isključivo na božanskom prvu nestabilna i, u najmanju ruku, nepoželjna opcija. Benavides, koji je ostao na španskom dvoru nakon Salasarove smrti, ubedio je Filipa II da bi urođenici trebalo da budu navedeni da sami zatraže kastiljanski suverenitet na Filipinima jer bi tako kralj bio priznat i prirodnim i božanskim zakonom i njegovo pravo na ubiranje danka ne bi moglo da bude dovedeno u pitanje. $U$ tom cilju, Benavides je 1598. god počeo da sprovodi naredbu po kojoj je guverner morao da podstakne Filipince u svim oblastima pod španskom vlašću da se dobrovoljno potčine španskoj kraljevini. Širom Manile i u susednim provincijama llokosa, Lagune i Pangasinana ${ }^{33}$ glavešine barangaja i njihovi sledbenici pozvani su da u prisustvu predstavnika španskih vlasti prihvate kastiljanskog kralja

32 Drugim rečima, kako bi špansko kraljevstvo ostvarilo duhovne ciljeve i otelovljenje apsolutne crkvene i božanske vlasti nad „nevernicima“, kleru je data privremena jurisdikcija nad urođenicima.

33 Dobrovoljno prihvatanje kastiljanskog suvereniteta potvrđuje činjenica da je u provinciji Lagune starešinama odobren rok od godinu dana pre konačnog izjašnjavanja, kao i to što je u Pangasinanu španska vlast prihvaćena pod uslovom prethodnog vraćanja naplaćenih poreza koji su smatrani nelegalnim jer u vreme njihove naplate provincija nije bila deo španskog kraljevstva. 
kao svog prirodnog gospodara i suverena. Ovaj čin zasnovan je na dogovoru o obezbeđivanju i pružanju određenih usluga između kralja i njegovih podanika, a od strane Španaca predstavljen je kao „oslobodilački“. Ukidajući paganske kultove, Španaci su tvrdili da oslobađaju Filipince od đavolskih sila i tiranije urođeničkih vladara. Kao zamenu za prihvatanje podaništva, kralj je Filipincima garantovao podučavanje katehezi, sprovođenje pravde i zaštitu od stranih neprijateljskih sila (Phelan 1957, 237-238). Međutim, iako su tokom XVII i XVIII veka španski kraljevi nosili titule vladara Indija, Novog sveta ili Amerike, pomenute titule više su imale retoričku vrednost i nisu iale precizno utvrđeno značenje pravnih normi. Takođe, iako u teoriji Filipini nisu bili kolonija metropole, već su imali ravnopravan status sa drugim kraljevstima Španije, u praksi to ipak nije bio slučaj.

Agrikulturna praksa Filipinaca bila je usko povezana sa kosmološkim shvatanjem zemaljskih i nebeskih energija i neka antropološka istraživanja ukazala su da je još u periodu pre španske vladvine na Luzonu u toku bila transformacija društvenog sistema. Naime, sawah zemljoradnici ${ }^{34}$ razvili su sistem akumulacije bogatstva zasnovan na posedovanju terasastih polja koja su nasleđivali ili sticali brakom. Na taj način, došlo je do promene u percepciji smrti koja više nije doživljavana kao nešto zlokobno, već kao mogućnost da se dobije dar od predaka, odnosno Boga. Samim tim ojačala je i ideja kulturnog paternalizma, što je olakšalo i prodor hrišćanstva. Istovremeno, iako je još u prehispanskom periodu filipinsko društvo bilo raslojeno, sa dolaskom Španaca proces stratifikacije je intenziviran jer su članovi vladajuće klase još jasnije utvrdili svoj elitni položaj u društvu.

Do XVI veka kuće su se već razlikovale po tipu i veličini, a počele su da se grade i one sa utvrđenjima i javljaju i ostali znaci rastuće društvene stratifikacije. Što je bio veći priliv robe iz inostranstva, vođe koje su kontrolisale trgovinske aktivnosti više su se izdvajale kao klasa imućnih koja je imala dobro izgrađene kuće pune luksuznih predmeta poput vaza od kineskog porcelana, svile, pamuka, zlatnih ukrasa, muzičkih instrumenata i predmeta ukrašenih duborezom. Međutim, ova novonstala elita nije samo gomilala bogatstvo nego ga je i stvarala. Tokom XVII veka ispunjen je minimum misionarskih ambicija. ${ }^{35}$ Parohije su formirane u skladu

$34 \quad$ Uzgajivači pirinča.

35 Sakramenti euharistije i pokajanja prihvaćeni su nominalno od strane nativnog stanovništva, ali su konfirmacija, poslednja pomast i posvećenje urođenika ostali strani duhovnom životu Filipinaca. 
sa grčko-rimskim arhitektonskim modelom koji je podrazumevo postojanje centralnog trga i mrežu ulica koje formiraju blokove. lako se može reći da je prvobitna faza hispanske urbanizacije Filipina bila samo delimično uspešna, napori španskog sveštenstva ka okupljanju stanovništva i formiranju sela i gradova postepeno su promili obrazac naseljavanja, olakšavajući prožimanje hispanske i filipinske kulturne matrice.

Ipak, nekadašnji kult moćnog vođe barangaja, koji je bio potpomognutog od strane božanskih sila, pretrpeo je suštinsku promenu u kojoj je postao ranjivija i ljudskija figura, tj. više pojedinac odabran da obavlja tehnničke poslove španskih vlasti. Kako je njegova osnovna funkcija preusmerena ka prikupljanju i naplati poreza u ime španskog kralja, status nekadašnjeg zaštitnika naroda degradiran je, a jedini način na koji je mogao da sačuva društveni ugled bio je udruživanje i potčinjavanje novim duhovnim vođama filipinskog naroda, tj. španskim sveštenicima.

\subsection{Vreme promena}

Nakon dobrovoljnog prihvatanja španskog suvereniteta (15981600) usledile su godine imperijalističke vladavine monarha iz dinastije španskih Habsburga. Međutim, sa dolaskom dinastije Burbona na vlast 1700. godine Savet Indija koji je bio zadužen za prekookeanske kolonije zamenjen je Ministarstvom spoljnih poslova (Ministerio de Ultramar), tj. institucijom poput postojećih u Engleskoj, Francuskoj i Holandiji. Na taj način, Filipini su umesto statusa španke provincije dobili status kolonije. Ovaj inferironi položaj bio je u potpunoj suprotnosti sa prvobitnim dogovorom između Filipinaca i Španaca i, iako je izazvao vidno nezadovljstvo među Filipincima, nije doveo do većih nemira.

Kada je nakon potpisivanja Utrehtskog sporazuma 1713. god. okončan rat za špansko nasleđe između Engleske i Nizozemske republike s jedne strane i Francuske i Španije s druge strane i podeljeni španski posedi u Evropi, ${ }^{36}$ merkantilistički duh je počeo je da se povlači pred

36 Nakon smrti Karlosa II, poslednjeg španskog Habzburga, u Evropi, Severnoj i Južnoj Americi između 1702. i 1714. izbio je rat za špansko nasleđe. Karlos II je verovao da su Burboni bili jedina sila koja je imala snage da očuva celovitost njegove imperije, zbog čega je u testamentu za naslednika imenovao Filipa, vojvodu anžujskog, drugog najstarijeg unuka francuskog kralja Luja XIV. Luj XIV je unuka proglasio za španskog kralja Filipa V i odmah zatim izvršio invaziju na špansku Nizozemsku i počeo da teži uspostavljanju dominacije nad trgo- 
prosvetiteljskim idejama XVIII veka. Intelektualna revolucija otvorila je put progresističkom internacionalizmu i napuštanju protekcionističke ekonomije u korist razvoja slobodne trgovine. Zapravo, u kraljevini su još od prve polovine XVIII veka bile izražene tendencije ka napuštanju monopolističke politike, posebno one koja se ticala filipinsko-meksičke trgovine, ali je program burbonskih reformi sproveden tek u drugoj polovini XVIII veka. Ove reformatorske ideje koje su proistekle iz liberalnih načela i podrazumevale modernizaciju fiskalne politike, privrede, uprave i vojske, ipak su počivale na jasno određenim interesima Španije.

Kako je Španija bila učesnica Napoleonskih ratova koji su usedili, posle neizbežnih političko-vojnih promena zatrebala joj je pomoć i podrška prekookeanskih podanika, te je vlast 15. oktrobra 1810. strateški usvojila Uredbu o prekookeanskim kolonijama kao sastavnim delovima kraljevstva i njegovim ravnopravnim članovima. Kasnije je Ustavom iz 1812. god. precizno određeno područje prekookeanskih teritorija i španske vlasti su zahtevale od Amerikanaca i Filipinaca da učestvuju u pomenutim borbama i odbrani svoje otadžbine. lako se stanovnici kolonija Zapadnih Indija, tj. Amerike, nisu jednoglasno odazvali ovom pozivu, već su ga u nekim delovima prihvatili kao poziv u borbu za sopstvenom nezavisnošću, žitelji Filipina verno su stali u odbranu španskih interesa kao sopstvenih. ${ }^{37}$

Nažalost, uprkos pokazanoj lojalnosti, španska politika ostala je burbonska. U skladu sa tim, 4. jula 1861. god. Španci su na Filipinima osnovali Administrativni savet (Consejo de Administración), a Filipini su po drugi put izgubili status redovne španske provincije i postali kolonija kraljevine. Osim toga, ustav Španije iz 1876. god. predvideo je da se na Filipinima, kao i drugim španskim prekookeanskim kolonijama (izuzev Kube i Puerto Rika), primenjuju posebni zakoni usvojeni nezavisno od pomenutog ustava. Na taj način, prvobitni stav pripajanja Španiji koji su Filipinci usvo-

vinom sa španskom Amerikom na račun engleskih i holandskih trgovaca, a odbijao je da ukloni Filipa iz linije nasleđivanja francuskog trona, ostavljajući tako mogućnost budućeg ujedinjenja Francuske i Španije, što je bilo neprihvatljivo za sva evropska kraljevstva. Sporazumom u Utrehtu potpisanim 1713. i Sporazum u Ramštatu iz 1714. god izvršena je podela španske imperije: Austrijanci su dobili većinu njihovih evropskih poseda, ali je vojvoda anžujski Filip zadržao iberijske i američke teritorije i priznat je kao kralj Filip V od Španije (Živojinović 1989, 234-239).

37 Kao nagrada za pokazanu odanost, 8. maja 1826. god. u Španiji je doneta Uredba o priznanju Manile kao prestonice Filipina i odlučeno je da se kao simbol njenog grba koristi kraljevska kruna na zamku. 
jili nakon dolaska Španaca potisnula je politička volja kraljevine usmerena ka potčinjavanju kolonije, stvorivši rastući jaz i koren filipinsko-hispanskog razdora (Molina 2005, 87-91).

Što se tiče uticaja kolonizacije na razvojni put filipinskog kulturnog sistema, hristijanizacija je uvela nova moralna načela i vrednosti, što se odrazilo na pitanje rodne ideologije i vrednosni sistem društva, ali je, sa druge strane, autohtona kultura suštinski odredila prirodu i razvoj domorodačke političke elite. Naime, kod Filipinaca je kulturni obrazac i preovlađujući vrednosni sistem neraskidivo ostao povezan sa političkim životom zajednice. Odnosi u filipinskom društvu bili su uvek hijerarhijske prirode, što je podrazumevalo vladavinu superiornijeg pojedinca kao "gazde“ u odnosu na koga su svi ostali u položaju „klijenta“. Ovakav odnos bio je prisutan i u odnosu zemljoposednika i radnika najmnika. Kao i zemljoposednici i političari su imali dužnost da pomažu svojim saradnicima koji su se zauzvrat ponašali kao zadovoljni „klijenti“ koji osećaju poštovanje i zahvalnost prema svojim pokroviteljima, što kulturološki izražava filipinsko utang na loob. ${ }^{38}$ Stoga, kao i u ostalim zemljama Jugoistočne Azije, i u filipinskoj kulturi razvoj elitne klase mora se posmatrati u okvirima autohtone kulturne tradicije i njoj svojstvenog vrednosnog sistema. Ovakav vrednosni sistem podrazumeva da su svi učesnici zbrinuti. U tom smislu, u filipinskoj kulturi ne postoji shvatanje apsolutne kontrole, već samo prilagođavanje datim uslovima. Političke vođe same po sebi nemaju značaj, jer zavise od reakcije naroda, tj. zajednice koja ih podržava. Na taj način, njihova moć nije statična, već je usmerena ka potrebama sledbenika (Mateo 2001, 15).

\section{Nacionalno buđenje}

Sa dolaskom Španaca i uvođenjem hrišćanstva, crkva je na sebe preuzela dvostruku ulogu i spasitelja i tlačitelja. Suštinski pobožni i radoznali Filipinci prihvatili su promene koje je donela hispanizacija. U stanju kulturološke dezorijentisanosti, preopterećeni dažbinama koje su plaćali

38 Od onoga ko je u podređenom položaju, tj. „klijenta“, očekuje se osećaj zadovoljstva jer je pod zaštitom jačeg, tj. gazde kome će se odužiti lojalnošću ili političkom podrškom.Ovakav stav svojstven je istočnjačkim kulturama. 
španskoj kraljevini i crkvi, Filipinci su zapravo svojim radom plaćali kolonizaciju i religijsku konverziju, kao i ratove koje je vodila Španija sa drugim zemljama i trgovinu galeona (Abinales and Amoroso 2005, 62-64).

Kao što je u predkolonijalnom periodu vladajuća klasa živela na račun plebsa putem iznuđivanja zakupnine zemljišta i prisiljavanja pripadnika niže klase da obrađuju njihova polja, tako je i kolonijalni aparat u stvari onemogućio poljoprivredni razvoj Filipina. Međutim, isto kao što je i pre dolaska Španaca filipinski narod znao da prepozna lošeg vođu i pobuni se protiv vladajuće klase, tako je i na kolonijalnim Filipinima XIX veka počelo da tinja nezadovoljstvo i da izbijaju ustanci koji su, iako u početku kratokoročni i lako ugušeni, vremenom dobili karakter revolucionarnih borbi usmerenih ka sticanju filipinske autonomije.

Neuravnotežena ekonomska politika filipinskog državnog aparata doprinela je razvoju socijalne nejednakosti između većine urođenika i mestičke elite. ${ }^{39} \mathrm{U}$ želji da unaprede administrativni aparat, vlasti su se zalagale za jačanje centralističke državne vlasti. Ipak, reforme sistema javne uprave bile su uslovljenje političkim dešavanjima u Španiji i specifičnim filipinskim društvenim uređenjem podeljenim između političke i klerikalne vlasti. ${ }^{40}$ lako je tokom XIX veka formiran novi ekonomski model u kome je zemlja bila osnovni resurs neophodan za proizvodnju i prodaju poljoprivrednih proizvoda na svetskom tržištu, na arhipelagu su se razvile zajednice sa različitim proizvodnim sistemima koje su se u različito vreme i pod različitim uslovima uključivale u svetske ekonomske tokove. Budući da Španija nije ulagala u razvoj privrede i izvoz, niti je uspostavila pravni okvir koji bi omogućio upravljanje ključnim ekonomskim resursima, filipinska ekonomija razvila se pod uticajem pojedinih stranih firmi koje su dovele do razvoja komercijalne poljoprivrede. Zapravo, preko lokalnih ogranaka anglo-američkih trgovačkih kompanija različiti regioni arhipelaga razvili su nezavisne veze sa globalnim kapitalističkim tržištem, ${ }^{41}$ a u razjedinjenim

39 Pošto je poreska stopa bila regresivna, poreski teret teže su podnosili zemljoradnici jer su plaćali porez po istoj stopi kao i zemljoposednici koji su ostvarivali visoke dohotke. Naime, verski redovi kontrolisali su posede koji su činili $40 \%$ teritorija četiri tagaloške provincije u okolini Manile koje su snabdevale grad prehrambenim proizvodima. Ipak, mnogo značajnije prihode ostvarivala su imanja pod kontrolom nove urođeničke elite na kojima se se gajili usevi za izvoz (79-80).

41 Pre XIX veka za filipinsku ekonomiju bio je tipičan trgovinski monopol, zbog čega su, barem formalno, Filipini bili zatvoreni za slobodnu trgovinu i saradnju sa inostranim tržištima. Ipak, u praksi, u mnogim lukama koje nisu bile pod direktnom španskom kontrolom u kon- 
lokalnim zajednicama razvijao se društveni jaz između rastuće siromašne radničke klase i novonastale ruralne elite, kao i netrpeljivost prema eksploatatorskom kolonijalnom sistemu (Abinales and Amoroso 2005, 184).

Ipak, uprkos postojećim pokretima otpora, početkom XIX veka još uvek nisu bile formirane elite ili društvene grupe koje su bile dovoljno ekonomski i politički jake da bi se organizovano suprotstavile postojećem kolonijalnom sistemu (Elizalde 2009, 65), a u želji da

potvrdi svoj status metropole, Španija je držala Filipince podalje od političke i ekonomske vlasti, dopuštajući im jedino da vrše određene funkcije na nivou loklane samouprave. Zapravo, Španija nije imala dovoljno sluha da prepozna političku situaciju u kojoj na Filipinima još uvek nisu ojačale separatističke struje, već su se samo razvile nove društvene grupe koje su zahtevale prilagođavanje kolonijalne politike njihovim političkim potrebama i veće izjednačavanje prava filipinskih i španskih građana. Drugim rečima, španska vlada nije bila svesna činjenice da je tokom XIX veka u filipinskom društvu došlo do suštinskih promena i da su se razvile nove društvene strukture, odnosno klasa intelektualne filipinske elite obrazovane na filipinskim, evropskim ili američkim univerzitetima, kao i krupne buržoazije koja je kontrolisala ekonomski razvoj različitih ostrva i regiona arhipelaga. Te elitne grupe bile su podržane širokom narodnom masom kojoj su pripadali kako nezadovoljni seljaci tako i nova urbana klasa i sekularni filipinski kler i bile su dovoljno snažne da se zauzmu za budućnost Filipina i pokrenu događaje od presudnog značaja za oblikovanje nacionalnog identiteta.

U takvom kontekstu, ponašanje Španije koja je u procesu formiranja liberalne države priznavala građanska prava Španaca, dok je ista uskraćivala Filipincima, bilo je u potpunosti kontraproduktivno. ${ }^{42} \mathrm{Da}$ bi opravdale udaljavanje filipinskih poslanika iz parlamenta, španske vlasti su

tinuitetu se trgovalo sa drugim zemljama i britanski i američki brodovi su pod okriljem lažnih azijskih zastava razemenjivali robu sa filipinskim trgovcima. lako je 1789. god. manilska luka prvi put delimično otvorena, tek je 1834. godine u potpunosti i zvanično otvorena za inostrano tržište (Elizalde 2009, 67). Naime, u španskom parlamentu bili su promovisani novi koncepti jednakosti i parlamentarnog uređenja koji su se takođe odnosili na kolonije, te je tokom kratkog perioda Španske buržoaske revolucije (Trienio Liberal 1820-1823) uslišen zahtev za uključivanje filipinskih poslanika u rad španskog parlamenta, ali je već tridesetih godina Filipincima uskraćeno pravo da imaju zastupnike u parlamentu i umesto toga svedeni su na posebne zakone kojima su zapravo njihova prava i slobode limitirani. 
kao opravdanje navele udaljenost kolonije od metropole, jezičku barijeru i eventualnu neisplativost uključivanja predstavnika kolonije čiji je mali broj stanovnika evropskog porekla, što bi moglo da izazove ogorečenost ostatka stanovništva. Na ovaj način, Filipini su isključeni iz liberalne politike koja je promovisana u Španiji i oduzete su im političke slobode i građanska prava, čime je bačena jabuka razdora koja će u budućnosti dovesti do raskida špansko-filipinskog odnosa. Usled konstantnog odbijanja Španaca da udovolje osnovnim zahtevima Filipinaca, tenzija među filipinskim stanovništvom je postepeno rasla, kulminirajući konačno revolucionarnom borbom za nezavisnost i sklapanjem saveza sa severnoameričkim zvaničnicima koji su Filipinima obećavali bolju budućnost (71-73). U tom smeru, od 1870. godine, intelektualci su se organzovali, oformivši u Manili pokret Propaganda (Movimiento de Propaganda) kako bi izdejstvovali ekonomsku modernizaciju i sprovođenje institucionalnih reformi koje bi omogućile vladavinu prava. Međutm, shvativši da ih Španija ne prihvata kao jednake niti ima nameru da uvaži njihove zahteve, pokret prosvećenih dobio je novu dimenziju i od 1890. god. započete su borbe za osamostaljenjem Filipina (Abinales and Amoroso 2005, 104 -105; Elizalde 1998, 318).

\subsection{Zaključna razmatranja}

U kulturološkoj analizi istorijskog nasleđa Filipina, nemoguće je prenebregnuti činjenicu da su Filipini oduvek bili arhipelag kulturne šarolikosti i tesnih etničkih i kulturnih prožimanja. Još u prehispanskom dobu ostrva su bila izložena jakom uticaju moćnih okolnih sila poput Kine, Japana, Indije i malajskih naroda. Takođe, trebalo bi imatu u vidu da je kolonijalna politika Španije prema Filipinima bila određena i dugotrajnom borbom protiv Mavara, tj. sukobom hrišćanske i muhamedanske kulture. Naime, dok su na istoku Francuska, Italija i Nemačka lako mogle da okončaju svoje učešće u krstaškim ratovima bez gubitka teritorija i nacionalne časti, Španija je morala da nastavi borbu protiv "neznanobožaca“ kako bi oslobodila deo svojih teritorija na zapadu. U tom cilju, jedan od glavnih ciljeva kraljevskih podanika na Filipinima bilo je pokrštavanje urođenika i njihovo preobraćanju u katoličanstvo.

Mali lučki gradovi-državice koji su se razvili zahvaljujući intentizvnim trgovinskim aktivnostima za vreme Ming dinastije imali su i više 
od 100.000 stanovnika i bili su napredni kosmopolitski i trgovački centri koji su okupljali različite narode Jugoistočne Azije (Kineze, Indijce, Arape, Turke, pa čak i trgovce iz Armenije). Nakon pada interesovanja kineskih careva za trgovinu na jugu ove lučke državice zadržale su status političkih, kulturnih i trgovačkih centara. Sa dolaskom Španaca u ovom periodu Filipini su se našli na istorijskoj raskrsnici u pogledu verskog i političkog uređenja. Budući da predstavljaju deo Jugoistočne Azije, mnogi su osudili hispanistički uticaj i pokrštavanje većine filipinskog stanovništva tokom XVI i XVII veka kao udljavanje od sopstvenog kulturnog identiteta. Ipak, posmatrano iz šire istraživačke perspektive, u kulturološkom smislu rani moderni period Jugoistočne Azije potvrdio je da se ovako krupne promene, poput verske konverzije, dešavaju tokom velikih promena $i$ potresa prethodnog poretka, što zapravo ukazuje na neadekvatnost i potrebu za promenama u starom sistemu vrednosti i verovanja. Period 1550-1650 je za celu Jugoistočnu Aziju bio upravo period ovakvih potresa i potreba za promenama. U tom smislu, za Filipine koji su postali meta osvajanja, poželjna trgovačka luka i baza za širenje hrišćanstva ka Orijentu, prodor islama, a potom i hrišćanstva, može se shvatiti kao logična posledica regionalnih potresa i potrebe za promenama. Istovremeno, ni jedan od pomenutih religijskih sistema nije se kosio sa verskim uverenjima zemalja Jugoistočne Azije, već je poput njih insistirao na duhovnoj povezanosti svetovnog i državnog (Reid 1993).

Sa druge strane, iako su priroda i razvoj domorodačke političke elite prvenstveno bili uslovljeni širim kontekstom filipinske kulturne matrice, hrišćanstvo koje je prodrlo na arhipelag ujedinilo je filipinski narod. To je bilo moguće jer su Filipinci kroz veru uspostavljali odnos ne samo sa Tvorcem ili Bogom, nego i sa bližnjima. Na taj način, ni u oblastima koje su Španci kolonizovali viša klasa nije uništena, već su njeni pripadnici pretvoreni u urođeničko plemstvo iz kojeg su regrutovani predstavnici vlasti, tj. prekršajne sudije. $U$ tom smislu, jedna od najupečatljivijih odlika hispanizacije svakako jeste zapanjujuće visok stepen, lakoća i brzina sa kojom su Filipinci usvojili španski politički sistem (Phelan 2011, 121).

Ipak, u slučaju filipinske nacije sačinjene od mnoštva različitih etničkih grupa konačno ujedinjenih u nacionalnom osvešćenju i borbi za izgradnjom sopstvenog političkog, kulturnog i duhovnog entiteta, značaj španskog kulturnog nasleđa iako nepobitan, relativnog je karak- 
tera. Naime, sama činjenica da je još u prehispanskom periodu u bilo kom trenutku figura poglavara mogla da bude odbačena od strane njegovih podanika, te samim tim i svedena na nivo pripadnika niže klase, ukazuje upravo na izgrađeni društveni totalitet razvijen oko antagonističke struje između vladajuće klase i klase potčinjenih. Drugim rečima, ukoliko narodni vođa nije bio u stanju da nametne svoju volju i utiče na konačnu odluku zajednice, njegova popularnost je opadala, a sledbenici su ga napuštali, okrećući se drugom, moćnijem vođi (Jocano 1975, 17). Stoga, može se zaključiti da je filipinskom društvenom poretku u izvesnom smislu bio srodan pojam feudalne eksploatacije, tj. prisvajanje viška rada ili proizvoda pripadnika niže klase koji su vođama barangaja bili dužni da isplaćuju feudalnu rentu bilo u vidu kuluka ili u vidu danka u naturi od letine, ili danka u novcu.

Ipak, iako u ovakvom hijerarhijskom sistemu nije bilo otvorene klasne borbe, stanovnici su imali razvijenu svest o potrebi da se suprotstave neprikladnim i preteranim pretenzijama gospodara i njihovo biranje boljeg poglavara zapravo je predstavljalo jedan vid otpora i snage da se upravlja sopstvenom sudbinom i insistira na uzajamnoj odgovornosti u odnosu između nadređenih i podređenih. Međutim, i pored razvijene samosvesti i izražene samosvojnosti, vladavina Španaca ostavila je vidljiv trag, posebno obeleživši ponašanje i način govora obrazovanih Filipinaca. Držeći do forme i ceremonijala prilikom opštenja sa drugima, Španci su preneli svoje manire urođenicima koji su bili veoma skloni podražavanju.

Međutim, ono što je zaista dovelo do prelaska sa tradicionalnog, verskog i kulturno-evropsko orijentisanog vrednosnog sistema na sekularni, anglosaksonski moderni kulturološki model, nije bilo suštinsko razmimoilaženje hispanskog i filipinskog kulturnog identiteta, već nestanak sa političke scene hispanko-filipinske generacije intelektualaca koji su priznavali kulturološku asimilaciju i osnovali pokret za izjednačavanje filipinskih prava sa španskim. Naposletku, tome su konačno doprineli revolucija 1896. i osnivanje Republike. Naime, tri generacije filipinskih istoričara formiranih pod uticajem američkog kolonijalnog režima, plasirale su koncept etničke čistote i odbacivanja španske i mestičke kulture. Na taj način, istorijski uticaj hispanizacije je omalovažen i odbačen, a geografsko-rasni faktor azijatskog, stavljen je u prvi plan kao nosliac filipinskog identiteta. Uprkos svemu, u analizi izgradnje filipinskog naciona- 
Inog identiteta nemoguće je prenebregnuti kolektivni identitet filipinskog naroda razvijan tokom hispanskog istorijskog perioda, isto kao što je nemoguće zanemariti autohtonu tradiciju samih Filipinaca ili spoljne civilizacijske faktore koji utiču na izgradnju bilo koje nacije.

\section{Literatura}

Abinales, Patricio N. and Donna J. Amoroso. 2005. State and Society in the Philippines. Lanham, New York, Oxford: Rowman \&. Littlefield Publishers, Inc.

Constantino, Renato. 1975. The Philippines: a past revisited. Quezon City: The Foundation for Nationalist Studies.

Cunningham, Charles Henry. 1974. The audiencia in the Spanish colonies as illustrated by the audiencia of Malina (1583-1800). [Millwood, NY]: Kraus Reprin

Earle, T K. 1987. "Chiefdoms in Archaeological and Ethnohistorical Perspective". Annual Review of Anthropology. 16 (1): 279-308.

Elizalde, Maria Dolores. 1998. "Filipinas, fin de siglo: imagenes y realidad". Revista De Indias (Madrid). 58 (213): 307-339.

Elizalde Pérez-Grueso, María Dolores. 2009. Repensar Filipinas: política, identidad y religión en la construcción de la nación filipina. Barcelona: Edicions Bellaterra.

Gonda, Jan, and Kamil V. Zvelebil. 1975. Handbuch der Orientalistik. Abt. 2, Abt. 2. Leiden: Brill.

Jocano, F. Landa. 1975. The Philippines at the Spanish contact: some major accounts of early Filipino society and culture. Manila: MCS Enterprises.

Junker, Laura Lee. 1996. "Hunter-gatherer landscapes and lowland trade in the prehispanic Philippines". WORLD ARCHAEOLOGY. 27 (3): 389-410.

1998. "Integrating History and Archaeology in the Study of Contact Period Philippine Chiefdoms". International Journal of Historical Archaeology. 02 (4): 291-320.

2000. Raiding, trading, and feasting: the political economy of Philippine chiefdoms. Quezon City: Ateneo de Manila University Press.

Mateo, Grace Estela C. 2001. The Philippines: story of a nation. Honolulu, Hawai'i: Center for Southeast Asian Studies, School of Hawaiian, Asian and Pacific Studies, University of Hawai'i at Manoa.

Molina, A. 2005. "Provincia, sí; Colonia, no". Revista De Comunicación De La SEECI, 0 (1): 81-92. doi:10.15198/seeci.1998.1.81-92

Monteverde y Sedano, Federico de. 1898. Campaña de Filipinas: la división Lachambre, 1897. Madrid: Librería de Hernando y compañia. http://resolver.staatsbibliothekberlin.de/SBB000013CE00000000.

National Exhibition of Filipino Pre-history and Culture. 1959. The Philippines in pre-historic times. Manila: Unesco National Commission of the Philippines.

Niziolek, Lisa C. 2013. "Examining changes in the organisation of earthenware produc- 
tion in a prehispanic Philippine polity using laser ablation-inductively coupled plasma-mass spectrometry". Open Journal of Archaeometry. 1 (1): 8.

Patanñe, E. P. 1996. The Philippines in the 6th to 16th centuries. San Juan, Metro Manila: LSA Press.

Phelan, John Leddy. 1957. "Some Ideological Aspects of the Conquest of the Philippines". The Americas. 13 (3): 221-239.

2011. The Hispanization of the Philippines: Spanish aims and Filipino responses, 1565-1700. Madison: University of Wisconsin Press.

Reid, Anthony. 1993. Southeast Asia in the early modern era: trade, power, and belief. Ithaca, N.Y.: Cornell University Press.

Sánchez Gómez, L. A. 1995. "Recent Philippine historical studies in Spain". ASIAN RESEARCH TRENDS. (5): 1-24.

Scott, James Brown. 1934. Francisco de Vitoria and his law of nations. The Spanish Origin of International Law. 1. Oxford: Clarendon press.

Scott, William Henry, and William Henry Scott. 1984. Prehispanic source materials for the study of Philippine history. Quezon City: New Day.

1992. Looking for the prehispanic Filipino and other essays in Philippine history. Quezon City: New Day.

Živojinović, Dragoljub R. 1989. Uspon Evrope: 1450-1789. Novi Sad: Matica Srpska.

\section{Sanja Stošić}

Faculty of Diplomacy and Security in Belgrade

\section{CULTURAL HISTORY OF THE PHILIPPINES - - FROM THE PROVINCE OF SPAIN TO COLONY}

\section{Summary}

In order to properly understand the nature of the Spanish colonial process in the Philippines, it is necessary to take into account the highly various historical circumstances under which took place not only the conquest and spiritual subjugation, but also the sociopolitical Hispanization of the islands. Spain's conquest of the oversea Eastern base had strategic value and, as such, the Philippines were strategically colonized and both militarily and financially supported by the Spanish empire. Namely, the overt political ambitions of the Spanish monarchy and the Roman Catholic missionaries' attitude toward proselytism have directly determined the peculiarities of colonial discourse and made significant changes in Philippine society. By appointing the Filipino leaders to the lower levels in the colonial system of government, the Spaniards established the 
traditional village organization and secured themselves an indirect rule. In rural areas of the Philippines, this kind of government enabled the formation of a 'new upper class' which in addition to political influence also enjoyed economic privileges and tremendous social prestige. The former friction between the indigenous communities without blood alliances ceased with the advent of superior political figures. Having succeeded in the acceptance of the Spanish sovereignty by the native population of Manila and neighboring provinces (Ilocos, Pangasinan and Laguna), during the 17 th \& 18th centuries the Spanish kings took the title of "natural" rulers of the Indies and, in theory, the Filipinos gained equal rights as of Spanish citizens. Nevertheless, the upcoming political events in the 18th and 19th centuries put in jeopardy the status of the Philippines as a regular province of Spain, revealing the Spanish policy aimed at subordinating the Philippine colony. In that sense, from the 16th to the 19th century the Philippine society went through a substantially transformative process in which the colonial system could not fuction as an unchangeable model within the different contexts, but rather acted as a kind of destructive force which was inevitably leading to he formation of cultural identity.

Key words: the Philippines, Spanish monarchy, colonization, political Hispanization, the local self-governemnt, cultural identitiy 